\title{
ANALYSIS OF THE EFFECT OF WORK STRESS AND WORK ENVIRONMENT ON EMPLOYEE PERFORMANCE AREMA AREMANIA BERSATU BERPRESTASI INDONESIA LTD.
}

\author{
Eirene Yonastasia Riyadi ${ }^{1^{*}}$ \\ Dwi Wulandari ${ }^{2}$ \\ Grisvia Agustin ${ }^{3}$ \\ 1, 2, 3 Faculty of Economics, State University of Malang, Indonesia \\ e-mail: erindnas91@gmail.com ${ }^{1}$,dwi.wulandari.fe@um.ac.id ${ }^{2}$, grisvia.agustin.fe@um.ac.id ${ }^{3}$ \\ *Correspondence: erindnas91@gmail.com
}

Submitted: 4 November 2021, Revised: 11 December 2021, Accepted: 14 December 2021

\begin{abstract}
One of the determinants of a company's progress, both service and non-service, is the resources it has. The company or a business entity feels that the company's goals will not be achieved without quality resources. However, they often do not realize that companies only make employees or their resources tools/assets to achieve company goals, not as individuals who need recognition and appreciation. This study aimed to analyze How much influence the work environment and work stress have on employee performance at Arema Aremania Bersatu Berprestasi Indonesia Ltd. In this study, the independent variables are Work Stress (X1) and Work Environment (X2), while the dependent variable is Employee Performance $(\mathrm{Y})$. This type of research is quantitative research analyzed using statistics. The number of samples obtained by using a saturated sample that makes the entire population of Arema Aremania Bersatu Berprestasi Indonesia Ltd. became a sample of 63 respondents. This Analysis uses multiple linear regression analysis. The results showed that Work Stress and Work Environment influence Employee Performance.
\end{abstract}

Keywords: work environment; work stress; employee performance. 


\section{INTRODUCTION}

Managing an organization in a company, human resources become a significant and central factor. An organization inevitably needs resources to manage the systems it contains to achieve its goals. Suppose human resources are not competent in an organization and the performance is not optimal, of course. In that case, this becomes a competitive problem that can bring an organization or company into a loss condition. On the other hand, if the human resources in the organization are competent and have good performance, it will support the organization's success in its goals.

The work environment is a set of things or factors that can directly or indirectly affect an organization or a company that will positively or negatively impact the work results of employees (Baskara et al., 2008). The working environment can be in rooms, layouts, facilities and infrastructure, and working relationships with colleagues (Rachmawati et al., 2021). The work environment is where employees perform their daily work (S. S. I. Siagian \& Khuzaini, 2015). A clean, pleasant working environment with neat, orderly, and circulating air, spacious rooms, and an environment that does not impede movement in the workplace can improve employee performance (Nawawi, 2005). The working environment plays a vital role in improving employees' work results (Kamarulzaman et al., 2011). If the working environment is comfortable and the communication between employees goes smoothly, work efficiency will indeed be maximized.
Job stress is an unpleasant psychological process that responds to environmental pressures (Robbins \& Judge, 2015). Job stress is a feeling of pressure experienced by employees when facing work. This can be seen from unstable emotions, feelings of restlessness, and increased blood pressure Mangkunegara (2009). Job stress arises because of negative thoughts such as employees' feelings of excessive obligations, work, and working hours. Work stress needs to be prevented because it will cause various negative impacts such as decreased productivity and worse performance due to decreased creativity and health problems.

This study is an evolution of a previous study (Isnaini, 2015) titled the Effect of work environment and job stress on employee performance. The difference between current research and previous research is that the research object used was different from the previous one, namely the Arema Aremania Bersatu Berprestasi Indonesia Ltd employees. Meanwhile, this research uses work environment and work stress as independent variables and dependent variables on employee performance.

According to Darmawan (2013), performance is an effort to obtain the best results from organizations, groups, and individuals through understanding and explanation within a framework of planned goals, standards, and attributes or compensation requirements mutually agreed upon.

According to (A. O. Siagian, 2021), stress is a condition of tension that affects a person's emotions, thoughts, and physical condition "meaning the employee 
479 | Analysis of The Effect of Work Stress and Work Environment on Employee Performance Arema Aremania Bersatu Berprestasi Indonesia Ltd.

concerned will face various negative symptoms, which affects his performance.

According to (Sedarmayanti 2011), the working environment is the set of tools and materials that predate his work both individually and collectively. Working environment is everything around the employee. Actions that may affect them in performing tasks. Tasks assigned, such as cleaning, music, lighting, and others.

The hypothesis is that the statement is temporary, but the truth is still low, it is necessary to test the truth or doubt about the relationship between two or more variables (Siregar, 2013). The hypothesis is a temporary response to the research problem formulation so that the problem formulation is often arranged in the form of a statement. Based on the existing research concepts, the hypothesis that will be tested in this study can be formulated as follows:

H1: Work Stress and Work Environment affect the Performance of Employees of PT. Arema Aremania Indonesia Bersatu.

H2: Work stress affects the performance of employees of PT. Arema Aremania Indonesia Bersatu.

H3: Work environment affects the performance of employees of PT. Arema Aremania Indonesia Bersatu

\section{MATERIALS AND METHODS}

\section{Design}

This research attempts to find answers to a problem with existing problems using a scientific approach. Judging from the problems examined, this study included research. Descriptive
Descriptive research is research that aims to describe existing phenomena. These phenomena can have forms, activities, characteristics, changes, relationships, similarities, and differences between one phenomenon and another.

\section{Population and Sampling Techniques}

1. Population

The population in this study was all employees at Arema Aremania Bersatu Berprestasi Indonesia Ltd. The population in this study was employees at Arema Aremania Bersatu Berprestasi Indonesia Ltd., totaling 63 employees.

2. Sample

The sampling technique used In this study, all members of the population were sampled or called saturated sampling. Saturated sampling is a sampling technique when all the population is sampled. This technique is usually used if the population is considered minor or less than 100 (Sugiyono, 2014). The sample used is all Arema Aremania Bersatu Berprestasi Indonesia Ltd. employees, totaling 63 employees.

\section{Research Instruments}

(Sugiyono, 2016) states that in social research whose instruments use a Likert scale, the data obtained are intervals. With a Likert scale, the variables are measured translated into variable indicators. Variable values with some tools can be expressed numerically, making them more precise, efficient, and communicative.

\section{Data Analysis Techniques}

The Analysis used in this study is quantitative data analysis, namely the 
Analysis carried out using statistical methods to determine the Effect of the work environment and work stress on employee performance. The Analysis used is Multiple Linear Regression, Classical Assumption Test, F-Test, and T-Test. Prior to the Analysis, the questionnaire will be measured as a data collection tool with validity and reliability tests.

a. Classical assumption

1) test Normality test Normality

The test's purpose is to determine if the data are typically distributed. Parametric Analysis such as regression requires the data to be normally distributed. Regression normality testing can use several methods: the standard probability curve (Priyatno, 2016). The decision is that if the data rotates around the diagonal and in the direction of the diagonal, then the regression model meets the normality assumption.

b. Test Multicollinearity

Multicollinearity is a state where the two variables independent or more in regression models occur in a linear relationship with perfect or near-perfect test multikolinieritas aimed at assuming no relationship (correlation) was perfect between independent variables with each variable, independent Sarwoko (2018). One of the methods used to detect multicollinearity is by looking at the value of the variance inflation factor (VIF) of each independent variable. If the value is VIF $>5$, there are symptoms of multicollinearity in the regression model.

3. The heteroscedasticity Test

The heteroscedasticity test of the linear regression model aims to assume that the residual variance is constant or the same for various observations or the absence of heteroscedasticity in the regression model Sarwoko (2018). The decision-making in this test of variance is that if the points spread out with an ambiguous sample and are less than zero on the $\mathrm{Y}$-axis, then in the regression model, there is no problem with variable variance.

\section{RESULTS AND DISCUSSION}

\section{RESULTS}

\section{The Characteristics of respondents}

the author took $100 \%$ of the population at Arema Aremania Bersatu Berprestasi Indonesia Ltd. That is as many as 63 respondents to be used as a sample.

\section{The results of the Analysis}

a. the normality test

Based on the results of the SPSS 22 norm test, it can be concluded that the pp plot shows that the points are distributed around the diagonal and tend to be in the direction of the diagonal. This means that the regression model in this study fulfills the assumption of normality. 
481 | Analysis The Effect of Work Stress and Work Environment on Employee Performance at Pt. Arema Aremania Bersatu Berprestasi Indonesia

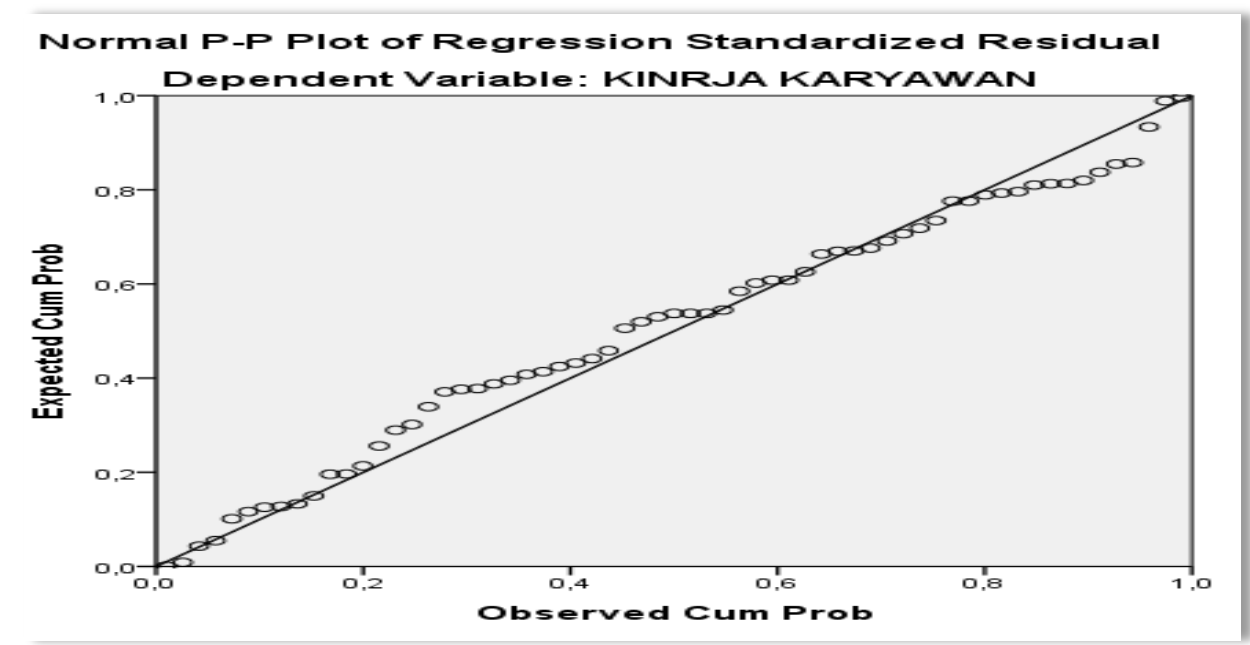

Figure 1. Normality Test Result

Table 1. Multicollinearity Test Results

\begin{tabular}{ccl} 
Variable & VIEW & \multicolumn{1}{c}{ Description } \\
\hline X1 & 2,079 & $<10$ There is no \\
X2 & 2,079 & multicollinearity \\
& & $<10$ There is no \\
& & multicollinearity \\
\hline
\end{tabular}

Source: Data processed 2020

b. Multicollinearity Test

Results The output value of SPSS for each variable $\mathrm{X} 1$ and $\mathrm{X} 2$ from the analysis results obtained that the VIF value is 2,079 , which is smaller than 10 , meaning that there is no perfect relationship between the independent variables. Thus it can be stated that there are no symptoms of multicollinearity in the model regression.

c. Heteroscedasticity Test

Based on the results of the test of variance in Figure 4.2, it can be seen that the distribution of the data does not form a definite (random) sample, so it can be said that there is no symptom of variable variance. Change in the regression model.

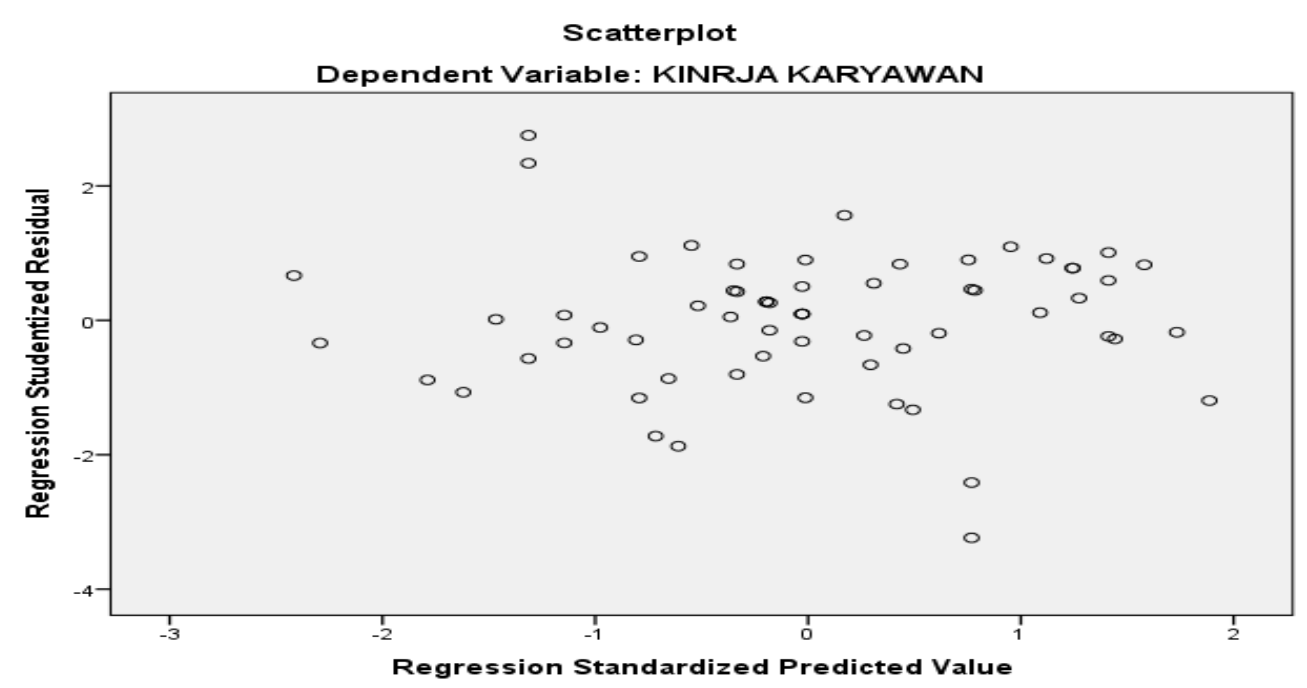

Figure 2. Heteroscedasticity Test Result 


\section{Multiple Linear Regression Analysis}

The results of the regression analysis between work stress (X1) and work environment (X2) on employee performance $(Y)$

a. $\beta=$ Regression test results 0.226 or $22.6 \%$, indicates that stress in the workplace (X1) has a positive effect on employee performance $(\mathrm{Y})$, which means that work stress increases and then performance increases

b. $\beta=$ the results of the regression test of 0.312 or $31.2 \%$ indicate that the work environment (X2) has a positive effect on employee performance $(Y)$, which means that if the work environment is more conducive/sound, it will affect employee performance to increase $(Y)$.

\section{The results of hypothesis testing}

Hypothesis 1

T-test results to test the significance of each variable can be partially explained as follows:

a. Line $X 1$ with $Y$ causal relationship

The analysis results were obtained by value $\mathrm{t}=3.063$ with a significant value $0.003<0.05$. It is stated that the causal relationship between $\mathrm{X} 1$ and $\mathrm{Y}$ is significant.

The results of the Analysis show that work stress affects a positive and significant impact on employee performance.

b. The path of the causal relationship between $\mathrm{X} 2$ and $\mathrm{Y}$.

The Analysis results obtained the value of $\mathrm{t}$-count $=3.248$ with $\mathrm{a}$ significant value of $0.002<0.05$. Thus, it can be stated that the causal relationship between $\mathrm{X} 2$ and $\mathrm{Y}$ is significant.

The results of the Analysis show that the work environment has an effect positive and significant impact on employee performance received

\section{DISCUSSION}

\section{Effect of Work Environment and Job Stress on Employee Performance}

Judging from these results, it can be concluded that simultaneous stress of work and the working environment both have a positive and significant effect on the performance of employees at Arema Aremania Bersatu Berprestasi Indonesia Ltd. This identifies that a good work environment is based on a conducive physical and non-physical environment and is based on task demands, personal tasks, a clear organizational structure, and effective organizational leadership.

Based on the results of previous research, Robin DK (2018) with the research title "Effect of stress at work and working environment on employee performance at PT Red Ribbon Indonesia." The results of this study indicate that work stress has a negative and insignificant effect on performance. While the study by Septianto (2010) with the research title is "Effect of work environment and work stress on the work performance of employees at PT Pattaya Raya Semarang." The results of this study indicate that work environment and work stress have a significant concurrent effect on employee performance. 
483 | Analysis of The Effect of Work Stress and Work Environment on Employee Performance Arema Aremania Bersatu Berprestasi Indonesia Ltd.

(Mochamad Syafii, 2016) with the research title "Effect of work environment and work stress on employee performance at Perum Perhutani, an independent business unit, Gresik timber industry, working environment and job stress, have a significant effect on employee performance. Concurrently and sufficiently impactful on the performance of the employees of Perum Perhutani, the independent business unit of the Gresik wood industry.

\section{Effect of Work Stress on Employee Performance}

Looking at the results of this study, it can be concluded that partially stress has a positive and significant influence on employee performance at Arema Aremania Bersatu Berprestasi Indonesia Ltd. This is known from the indicators of task demands for employees, interpersonal demands or employee relations, organizational structure, organizational leadership are things that must be considered by companies and company leaders so that employees can control work stress and be able to control the workload given to employees.

(Isnaini, 2015) with the research topic "Effect of work environment and stress at work on employee's work performance (Case study at PT Putra Nugraha Sentosa Mojosongo. Stress in the workplace. Mahardiani (2013) with the research title "Effect of work stress and physical work environment on employee performance outsourcing At PT. Bank Jateng, branch and coordinating branch of Semarang city It is suggested in this study that the company should pay more attention to the situation. Outsource the company's employees to be able to improve the company's performance better.

\section{Effect of Work Environment on Employee Performance}

Based on the results of this study, it can be concluded that partially the work environment has a positive and significant influence on employee performance at Arema Aremania Bersatu Berprestasi Indonesia Ltd. Based on the results of previous research conducted by (Yunanda 2013), of course by paying attention to several indicators of its influence, such as the influence of the non-physical environment and the physical environment so that company leaders can pay attention to them to achieve a high level of employee performance. (Study at Perum Jasa Tirta I Malang, Water Quality Laboratory Section). Based on this research, there is a significant effect between the work environment variables on the performance variables of the Jasa Tirta I Public Company employees. Further research indicates a significant influence between the job satisfaction variables on the employee performance variables. In addition, the results of this study indicate that there is a significant effect between work environment variables on employee job satisfaction variables.

\section{CONCLUSIONS}

Based on the Analysis and discussion of the results of the hypothesis tests that have been performed, several important conclusions are drawn, which are central to the results of this study. Work stress has a 
positive and significant effect on employee performance at Arema Aremania Bersatu Berprestasi Indonesia Ltd. Based on multiple regression linear analysis in this study, and it was obtained that direct work stress affected performance. The work environment directly affects Arema Aremania Bersatu Berprestasi Indonesia $L t d$. These results indicate that a conducive environment determines how a company can create a high performance for employees and impact employee performance. Work Stress and Work Environment simultaneously affect the performance of employees at Arema Aremania Bersatu Berprestasi Indonesia Ltd. based on the coefficient of determination and the $f$ test.

\section{REFERENCES}

Baskara, A., Soetjipto, H. P., \& Atamimi, N. (2008). Kecerdasan emosi ditinjau dari keikutsertaan dalam program meditasi. Jurnal Psikologi, 35(2), 101115. 10.22146/jpsi.7947

Darmawan, D. (2013). Prinsip-Prinsip Perilaku Organisasi. In Surabaya Pena Semesta.

Ghozali, I. (2019). Aplikasi Analisis Multivariate Dengan Program SPSS.

Isnaini, K. (2015). Pengaruh Lingkungan Kerja dan Stres Kerja Terhadap Kinerja Karyawan (Studi Kasus pada PT. Putra Nugraha Sentosa Mojosongo). Universitas Muhammadiyah Surakarta.

Kamarulzaman, N., Saleh, A. A., Hashim, S. Z., Hashim, H., \& Abdul-Ghani, A. A. (2011). An Overview of The Influence

$\begin{array}{lcr}\text { of Physical } & \text { Office } & \text { Environments } \\ \text { Towards } & \text { Employee. } & \text { Procedia } \\ \text { Engineering, } & 20, & 262-268 . \\ \text { https://doi.org/10.1016/j.proeng.2011 } \\ .11 .164\end{array}$

Mangkunegara, A. P., \& Prabu, A. (2009). Manajemen Sumber Daya Manusia. Bandung: PT. Remaja Rosdakarya.

Mochamad Syafii, T. L. (2016). Pengaruh Lingkungan Kerja dan Stres Kerja Terhadap Kinerja Karyawan di Perum Perhutani Kesatuan bisnis mandiri industri kayu gresik.

Nawawi, H. H. (2005). Perencanaan SDM untuk Organisasi Profit yang Kompetitif. Yogyakarta. Gadjah Mada University Press, Bulaksumur. Cetakan ketiga.

Priyatno, D. (2016). SPSS Handbook. In Yogyakarta, Mediakom.

Rachmawati, S. N., Lumbanraja, P., \& Siahaan, E. (2021). The Effect of Adaptive Ability, Communication Skills, and Work Environment on Performance of Medan Mayor's Office With Teamwork as Intervening Variables. Journal Research of Social Science, Economics, and Management, 1(4), 406-417. https://doi.org/10.36418/jrssem.v1i4. 37

Robbins, S. P., \& Judge, T. A. (2015). Perilaku Organisasi (Organizational Behavior 16th edition). Jakarta: McGraw Hill Dan Salemba Empat.

Sedarmayanti. (2011). Tata Kerja dan Produktivitas Kerja. In Bandung, CV Mandar Maju.

Siagian, A. O. (2021). Pengaruh Disiplin 
485 | Analysis of The Effect of Work Stress and Work Environment on Employee Performance Arema Aremania Bersatu Berprestasi Indonesia Ltd.

Kerja Karyawan Terhadap Produktifitas Karyawan PT. Sahabat Unggul Internasional. JENIUS (Jurnal Ilmiah Manajemen Sumber Daya Manusia), $4(2)$, 201-215. http://dx.doi.org/10.32493/JJSDM.v4i 2.9091

Siagian, S. S. I., \& Khuzaini, K. (2015). Pengaruh Pelatihan, Kepuasan Kompensasi, Motivasi dan Disiplin Kerja Terhadap Kinerja karyawan. Jurnal Ilmu Dan Riset Manajemen (JIRM), 4(5).

Siregar, S. (2013). Metode Penelitian Kuantitatif: Dilengkapi Dengan Perhitungan Manual \& SPSS.

Sugiyono. (2014). Metode Penelitian Kuantitatif Kualitatif dan R\&D (12th, Cetaka ed.). CV Alfabeta.

Sugiyono. (2016). Metode Penelitian Kuantitatif, Kualitatif dan R\&D. PT Alfabet.

Yunanda, M. (2013). Pengaruh Lingkungan Kerja dan Kepuasan Kerja Terhadap Kinerja Karyawan (Perum Jasa Tirta I Malang Bagian Laboratorium Kualitas Air). Universitas Brawijaya.

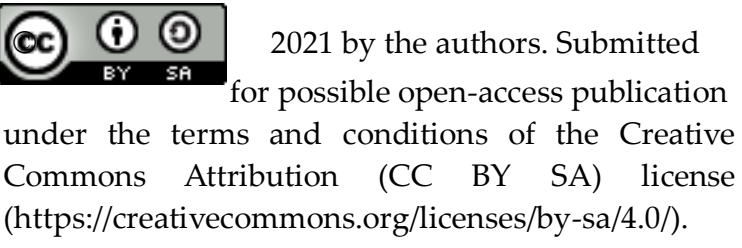

